\title{
A ATUALIDADE DA TEMÁTICA DE RAÇA E ETNICIDADE EM UM ESTUDO SOBRE A (DES)AFRICANIZAÇÃO DO EGITO ANTIGO
}

Raisa Sagredo ${ }^{1}$

Defendida no início do ano de 2017 no Programa de Pós-Graduação em História da Universidade Federal de Santa Catarina, a dissertação de Mestrado intitulada Raça e Etnicidade: questões e debates em torno da (des)africanização do Egito Antigo, trouxe à tona reflexões de longa data, somados a intensos debates atuais sobre a questão. Orientada pelo especialista em África do Departamento, Prof. Dr. Sílvio Marcus de Souza Correa, a dissertação propôs-se justamente a fazer uma análise do fenômeno da (des)africanização do Egito Antigo dentro da historiografia e da Egiptologia. O tema, por mais que possa parecer já superado para alguns, mostra-se ainda hoje um terreno fértil para disputas de identidades e feridas pós-coloniais, onde a categoria "raça" acaba sendo apropriada tanto por discursos que defendem a branquitude como a negritude dos antigos egípcios.

Longe de ser uma problemática recente, o chamado imbróglio do Egito inicia com o processo onde o Egito é arrancado do universo africano pelo eurocentrismo e pelo orientalismo, fazendo com que seja arbitrariamente relacionado geograficamente, antropologicamente e culturalmente à Ásia ocidental e ao mundo mediterrâneo apenas. O Egito "branco" já era contestado por Volney, viajante do século XVIII, Firmin e Douglass, intelectual e ex-escravo norte-americano no XIX, vindo a ganhar maior visibilidade no movimento Pan-africanista e suas reivindicações contra o racismo.

Com os estudos do egiptólogo senegalês Cheikh Anta Diop no início do XX é que a chamada negritude dos antigos egípcios foi sistematizada e pesquisada dentro das ciências, sendo um legado que permanece através do chamado Afrocentrismo Kemético. ${ }^{2}$ Este, coexiste com a memória hegemônica de um Egito deslocado de África e branqueado, percebido e

\footnotetext{
${ }^{1}$ Mestre em História pela Universidade Federal de Santa Catarina, Curitiba, Brasil. Email: nefertitisagredo@gmail.com

2 A expressão Afrocentrismo Kemético é assim chamada em função de uma das teses de Diop, onde o termo kemet ou kemit - transcrição da palavra kmt - seria traduzida por "negros" ou "homens pretos" segundo Diop.
} 
perpetuado através dos imaginários e da maioria das representações desse passado faraônico.

Ao historicizar a questão, constata-se como a racialização da historiografia do Egito vem a implicar direta e indiretamente nas perguntas feitas a esse passado, e como

moldam as formas de se conceber o mesmo, remetendo, no entanto, às teorias raciais do século XIX e à própria construção de um saber, a Egiptologia. Visa, ainda, conceber como os debates acerca da etnicidade podem ser uma interessante estratégia em discussões tão polarizadas. Mais especificamente com relação ao Egito faraônico, estes estudos vêm sendo feitos já há algumas décadas, no entanto, a problematização do binarismo ainda se torna necessária, pois como analisado na recene bibliografia, os debates raciais seguem intensos. A partir de leituras póscoloniais, decoloniais, em diálogo com a Antropologia, é possível um questionamento acerca da pertinência de categorias-chave empregadas nessa (des)africanização, desde seus conceitos até seu uso dentro da História Antiga - como o conceito de raça. Deste modo, parece ser possível compreender a subjetividade dos processos que levaram socialmente ao imbróglio do Egito, propondo um balanço crítico que reflita sobre as consequências epistemológicas e historiográficas das diferentes abordagens.

O que a dissertação traz de novidade é a proposta de historicizar o binarismo presente nos discursos sobre (des)africanização do Egito, propondo justamente romper com a lógica da racialização, introduzindo os estudos existentes sobre etnicidade na Antiguidade e dialogando com as contribuições brasileiras para a questão. Como a questão racial repercutiu no Brasil em termos de Egiptologia? Como o exemplo do Egito negro reivindicado pelo Olodum e movimentos carnavalescos brasileiros podem auxiliar a perceber como o Afrocentrismo repercutiu no país? Por isso a importância de perceber como essa racialização foi sendo construída e sistematicamente introduzida na História Antiga, fazendo um balanço crítico de uma vasta bibliografia.

Na pesquisa, utilizou-se também contribuições advindas da Arqueologia pós-colonial, diálogos com pensadores decoloniais, dos aportes desdobrados a partir de Barth e incluiu-se discussões contemporâneas e pesquisas novas com relação à Núbia e o novo olhar sobre uma memória anteriormente tão subalternizada por tantos séculos, auxiliando a romper abordagens de unidirecionalidade e hierarquização culturais e raciais. Exemplificando a atualidade de tais reivindicações tantas vezes unidirecionais, trouxe-se para o debate bibliografia recente a partir da 
chamada Egiptologia Africana e seus principais expoentes da atualidade, Obenga e Asante. Foram inseridas a chamada crítica americana ao Afrocentrismo Kemético (Lefkowitz, Montellano, Moses, Walker), a crítica francesa (Henry Tourneaux et al), e as críticas de intelectuais africanos como Mbembe e Appiah acerca de identidade africana e racialização em África.

Atentar para as subalternizações presentes em ambas as perspectivas tanto na afrocentrista como em sua crítica - e, mutatis mutandis com relação ao peso e concepção de raça contida em ambos, a perspectiva das etnicidades não nega nem ignora as apreciações anteriores. Penso que as discussões acerca de etnicidade na Antiguidade egípcia são parte deste movimento. Este desafio dialoga diretamente com os debates do cenário brasileiro sobre a questão racial, o ensino de História de África e a Lei 10.632 .

Ao encontro das discussões atuais sobre História Global, esta dissertação constitui-se de mais um esforço de pensar, como tanto defende Costa e Silva, um Egito Antigo situado na esquina do Mundo Antigo (2006), concebendo e lembrando um Egito para além da sua geografia africana, que contribui demasiadamente para a historiografia, Egiptologia e para os debates acerca da africanização do Egito. Juntos, estes três aspectos podem auxiliar na desconstrução da ideia de centro e periferia, que transparecem, tanto dentro do Eurocentrismo quanto do Afrocentrismo Kemético. 